\title{
Contested Knowledges in the Environmental Conflict over Uranium and Phosphate Mining in Ceará - Brazil
}

\author{
Raquel Maria Rigotto \\ Faculdade de Medicina, Departamento de Saúde Comunitária, Programa de Pós-graduação em Saúde \\ Coletiva, Universidade Federal do Ceará, Fortaleza, CE, Brasil
}

\begin{abstract}
This article analyses aspects of knowledge production in situations of environmental conflicts. It focuses on the context of the environmental field established by the announcement of the uranium and phosphate mining project in the Sertão Central (Central Hinterland) of Ceará - Brazil. The aim is to describe several modus faciendi - ways of acting - that update and territorialize epistemicide and cognitive injustices in the context of neo-extractivism. It also intends to describe processes of knowledge construction put in motion by subjects who were affected, in order to defend themselves from threats to their territories and ways of life. The study also addresses interfaces of this process with the participation of researchers/advisors who, from the perspective of a science oriented by activism, engage in dialogue with local subjects for a shared production of knowledge.
\end{abstract}

Key words: knowledge; development; environmental conflict; uranium and phosphate mining. 


\section{Conhecimentos em disputa no conflito ambiental em torno da mineração de urânio e fosfato no Ceará - Brasil}

\section{Resumo}

O artigo examina aspectos da questão do conhecimento produzido em situações de conflitos ambientais, tomando como base o campo ambiental conformado a partir do anúncio do projeto de mineração e beneficiamento de urânio e fosfato no Sertão Central do Ceará - Brasil. Propõe-se a caracterizar alguns modus faciendi que atualizam e territorializam o epistemicídio e as injustiças cognitivas no contexto do neoextrativismo, bem como os processos de construção de conhecimentos acionados pelos sujeitos afetados, no intuito de defenderem-se das ameaças a seus territórios e modos de vida. Aborda ainda as interfaces deste processo com a participação de pesquisadores-assessores que, na perspectiva de uma ciência orientada pelo ativismo, engajam-se no diálogo com os sujeitos locais para a produção compartilhada de conhecimentos.

Palavras-chave: Conhecimento; Desenvolvimento; Conflito ambiental; Mineração de Urânio e fosfato. 


\title{
Contested Knowledges in the Environmental Conflict over Uranium and Phosphate Mining in Ceará - Brazil
}

\author{
Raquel Maria Rigotto
}

\section{Introduction}

They told us some things about their work, and we followed it closely, asking how these things worked. They [CPRM field researchers] did some drillings to a depth of 600 meters, looking for uranium. They said that these drillings, some of which began in the mud, soon reached uranium, before reaching one hundred meters. When they reached six hundred [meters] they were still finding uranium. Yes, I followed this, through information from the others. Because people don't have a lot of knowledge about this and we don't understand it very well (interview with resident of Riacho das Pedras, Santa Quitéria, in Monteiro Junior 2017: 121).

At the beginning of the 1970s, some local residents first learned of the existence of the Itataia uranium and phosphate mineral deposit in their region while serving drinking water to the geologists of the state Mineral Resources Research Company (CPRM). In the context of the oil crisis and the Cold War, the civil-military dictatorship (1964-1985) searched for alternative sources of energy - including nuclear - to sustain development. This was accomplished with the help of technology transfer provided by the BrazilGermany Nuclear Cooperation Accord (since 1975) and, domestically, by the National Council of Scientific and Technological Development (CNPq) which, since post-World War II, had been responsible for nuclear energy research centered at that time at the Universidade de São Paulo.

Four decades later, agrarian reform settlements, peasant communities and residents of the cities of Santa Quitéria and Itatira continue digging for information about the successive projects of exploration of the mineral deposit - denoted by natives as a "sleeping dragon". They try to evaluate the consequences of such projects for their lives in that semiarid region of Ceará state, in the northeast of Brazil (Figure 1): "and if that mine does become a reality here, what will become of us?"

Figure 1 - Maps locating Ceará state in Brazil and the municipalities of Santa Quitéria and Itatira in the central hinterland of the state.

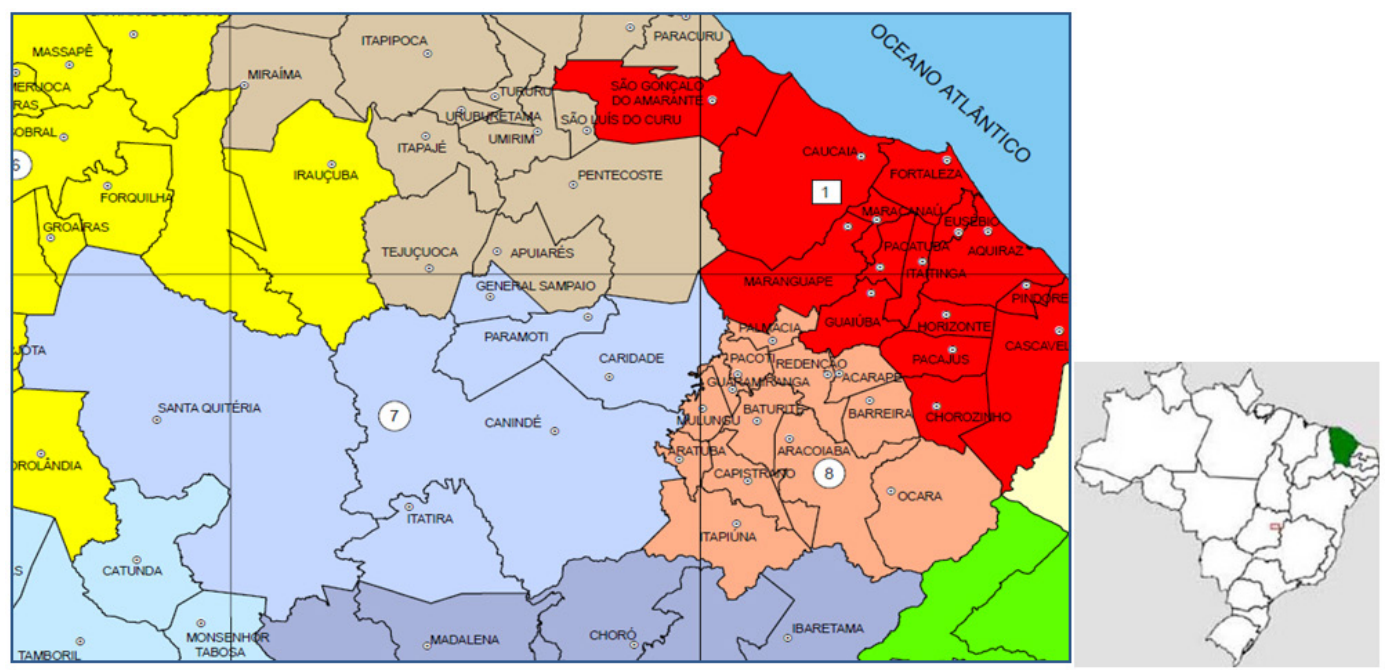


In the context of the division of labor and nature imposed by advanced capitalism, environmental conflicts spread across regions such as Latin America and Africa (Svampa 2016), where large mining and agribusiness enterprises are established. These large projects, together with the infrastructure which they require, result in new territorialities, strange to the living places of a variety of traditional peoples and communities. Affected by dispossession and the degradation of the ecosystems which sustain their lives, they are exposed to serious violations of rights - to the land, territory, culture, environment, dignified work, health, among others -, a situation of environmental inequalities and injustices.

In this dispute over material and social appropriation of nature, distinct rationalities confront one another: on the one hand, space as a source of accumulation and, on the other, space as a source of memory, identity and reproduction of modes of living (Laschefski 2011). This confrontation is established from the very beginning, since the announcement of the project - the phase in which the economic agents, often accompanied by State agents, operate to obtain not only the environmental license, but also the so-called "social license to operate" - as denoted by the business sector.

Thus an environmental field is constituted - as "space of social relations, structured hierarchically and which is marked by a game between social actors which dispute", among other things, "the definition and practices related to the ideas of sustainability, development, environment, etc." (Zhouri 2012:47). In this environmental field, debates begin with the evaluation of the enterprise, its repercussions for the place, the good and the evil it will bring. Most often, these debates are characterized by a sharp asymmetry of power. Various social actors face one another, each defending their interests and values, which are often contradictory, and not always explicit, thereby constituting cognitive-political conflicts (Acselrad 2014). In this dispute, knowledges - scientific and popular - are also at stake, involving "the unequal distribution of economic, political and symbolic capital, which locate the agents in the field, making available to them distinct powers to enunciate and assert their respective political projects (Zhouri and Oliveira 2013: 80).

Social groups affected by development projects, which seek to be part of this environmental field, believe that their concerns are frequently not considered. The access, itself, to information about the project is difficult, with respect to characteristics of the project, risks involved and guarantees for those affected. Such information, vital to allow subjects in their territories to understand, evaluate and form an opinion, is often difficult to obtain, or is incomplete, written in language which is difficult to understand, biased or distorted by the prior political decision to implement the project. Adding to these problems is the difficulty for these groups to evaluate the implications of the project for their way of life, especially since it involves technological risks about which they have no prior experience or collective memory.

The situation becomes even more confusing for these local subjects when they have to face, in the public arena, scientific controversies and the political use of uncertainties, which is "a form of disqualifying the questioning of dramatic socio-environmental effects produced by the implementation of public goals defined by the modernizing project" (O'Dwyer 2014: 13). If, on the one hand, public understanding of science confers to it authority in the social arena, on the other hand, the expertise of scientific actors is frequently "used to legitimate spatial practices seen as environmentally harmful" (Wynne 2014: 85), considering that "the production of scientific knowledge becomes increasingly incorporated into market dynamics and its management mechanisms", and universities are also reconfigured as "knowledge corporations" (Zhouri and Oliveira 2013: 75).

Analyzing the interlacements between policies of knowledge and "development", Acselrad (2014) discusses the conditions for the production, in universities, of an autonomous and critical thought which would destabilize developmentalism by introducing uncertainty to the notion of progress, having as references the "interests approach" and the "cultural properties of science" (p. 98-10o). He identifies, among different logics inscribed in cognitive disputes, "elements of a lay, contextual and situated 
epistemology", constructed by affected communities to defend themselves from suspect expert discourse and from risk and damages which are imposed on them. The author also mentions "epistemic subjects of the democratization of cognitive powers", who "become involved in cognitive struggles to deconstruct ethnocentric epistemologies and demonstrate political dimensions of the field of knowledge: next to the ecology of knowledge they propose, similarly, an ecology of powers)" (p. 101).

Along similar lines, Zhouri and Oliveira reflect upon the various incursions of anthropology into cognitive disputes which involve environmental impact assessment processes - consulting firms that evaluate environmental impacts, technical personnel in State agencies, expert analysts and advisors. The authors underline the role of the latter group as "supporting actors, assisting the active participation of local subjects", guided by a militant anthropology, aware of "the possible effects and political consequences which result from forms of appropriation of this knowledge" (Zhouri and Oliveira 2013: 103, 98).

In this direction of engagement with the demands of the research subjects, researchers are challenged to abandon the methodological recommendation of neutrality, a fiction which corresponds "implicitly, to the naturalization of relations of domination between asymmetric social groups inserted in a colonial framework" (Pacheco de Oliveira 2013: 55). They also find the need to dialogue with other disciplinary fields, since the challenges of research also require knowledge "from medicine to pedagogy, from law to geography, from music to mathematics, from video to agronomy” (p. 68).

Thus, in this article we will analyze aspects of knowledge production in situations of environmental conflicts, having as empirical case the environmental field formed by the announcement of the uranium and phosphate mining project in Ceará. We propose to describe several modus faciendi - ways of acting - that modernize and territorialize epistemicide and cognitive injustices of contemporary advanced capitalism (Santos and Meneses 2010), and highlight the reaction of affected subjects, through processes of knowledge construction which strengthen their position in the social field with the purpose of defending themselves from threats to their territories and ways of life - lay epistemology. The study also addresses the interfaces of this process with the participation of researchers/advisers who, from the perspective of a science oriented by activism (Martinez Alier et al 2011; 2014), engage in dialogue with local subjects for shared production of knowledge.

This article is based on reflections raised by the insertion of the Nucleus of Labor, Environment and Health - Tramas, of the Federal University of Ceará - UFC in the territory in which the uranium and phosphate mining project is proposed. The group has conducted research in this territory since $2010^{2}$. These research processes involve interaction with subjects in field activities, in communities and settlements, in public hearings, seminars, and public demonstrations, as well as in the involvement as member of the Articulação Antinuclear de Ceará - AACE, together with the Landless Workers Movement - MST, the Land Pastoral Commission - CPT, and the NGO Caritas, of the Sobral Catholic Church.

\footnotetext{
1 The TRAMAS Nucleus is a research and extension group of the Federal University of Ceará, linked to Graduate Programs in Collective Health and Development and Environment. Its focus is the framework of health-labor-environmental interrelations in environmental conflicts and is composed of professors and students from a variety of academic backgrounds, specifically, Biology, Medicine, Law, Pedagogy, Social Sciences, Communication, Theater and Social Service.

2 See Teixeira 2013; Alves, 2012, Nunes 2013; Rigotto et al. 2014; Montezuma 2015; Costa 2015; Melo 2015; Ribeiro 2016; Brasileiro 2017.
} 


\section{Modus faciendi of the epistemicide and cognitive injustice in the central hinterland of Ceará and the construction of resistance}

Since the discovery of the Itataia mine, in the 1970s, various mining projects were drawn up and have become a recurrent theme in election campaigns over the course of this period. They repeatedly appear in state and municipal government plans for development and as "natural vocation" of the region, in narratives which lead towards the construction of a local identity marked by this promise.

In 2004, a uranium and phosphate mining and processing development project was announced and the debate heated up once again; but in 2010, the environmental license obtained by the entrepreneurs was annulled in action taken by the Public Ministry, due to procedural irregularities. Since then, in a new initiative, the Santa Quitéria Project was proposed by the consortium composed of, on the one hand, Brazilian Nuclear Industries - INB (state enterprise) and Galvani Industries, Commerce and Services S.A. (private enterprise) - which acts in the production and sale of phosphate fertilizers - and, on the other hand, the multinational Yara, enterprise of Norwegian origin which, since 2014, is majority shareholder of Galvani. The objective of the project, which is currently (February 2017) in the environmental impact assessment phase, is to explore, extract and process 65.6 million tons of phosphate and 80 thousand tons of uranium in twenty years. Their installations consist of a mine, a separation and processing plant, a sterile waste pile, a phosphogypsum stack and a tailings dam (Figure 2).

Figure 2 - Map locating installations of the Santa Quitéria uranium and phosphate mining and processing project, Ceará - Brasil. Source: Arcadis Logos 2014a

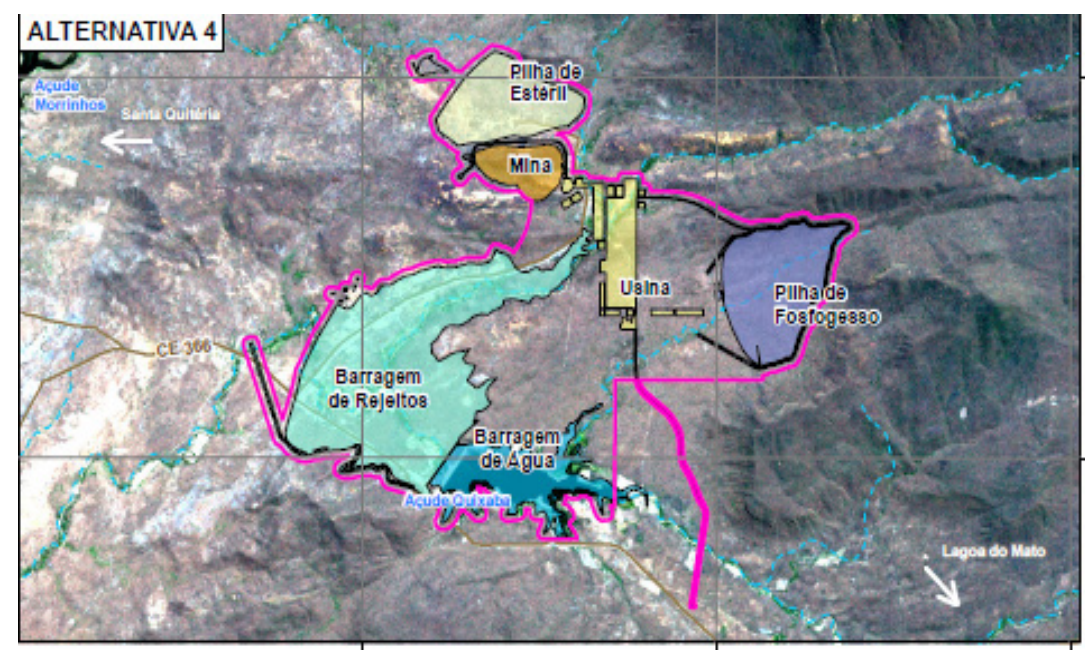

In this context of the announcement of the Santa Quiteria Project, the topic of the mining project has become ever-present in conversations among residents, in schools, in the media and in public debates, forming a field in which the social license of the project is in play and in which various actors produce and disseminate narratives which tend to be polarized between "pro" or "con": the entrepreneurs and their experts, public authorities and their technical staff, representatives of the legislature, urban and rural residents, merchants, liberal professionals, landowners, social movements, researchers, and others. In this scenario, which constitutes an environmental conflict (Svampa 2016), the actors draw on a diversity of knowledges - from native to specialized - and develop strategies for the symbolic dispute over the meaning and implications of the project for the place, which will be presented as follows. 


\section{a) Disqualification and reaffirmation of local knowledges and ways of life}

In the justification of the mining project to local society, the consortium presents itself as an entrepreneurial answer to an important national need:

\section{WHY DO WE NEED THE SANTA QUITÉRIA PROJECT?}

Brazil needs basic inputs, such as phosphate-based fertilizers, in order to produce more food. Currently, a large part of these basic inputs are imported. At the same time, we need to generate sufficient non-polluting energy for food production and other purposes. One of the clean energy alternatives is the energy produced in nuclear plants. Why not, therefore, have a project which brings together, at the same place, phosphate extraction to produce agricultural fertilizers and animal feed and, in addition, produces uranium for the generation of electric energy? (Arcadis Logos 2014b: 6).

The initial question - "Why do we need the Santa Quitéria Project?" - aims to establish a "we" that would unite the interests of all social segments in support of the project, to induce a conclusion that "we need it". The justification for the project operates with a supposed universal consensus regarding the need for increased food production in Brazil. However, studies indicate that the problem is not the volume of food produced, but the use of technologies brought about by the conservative modernization of agriculture, such as chemical fertilizers, when there are other conceptions and living alternatives in the territory, such as organic agriculture and agroecology,

The Environmental Impact Study - EIA - required by Brazilian legislation as the basis for environmental licensing is carried out by the Arcadis Logos consulting firm, under contract to project entrepreneurs. The EIA provides official data about "low educational level" and classifies the population as "uneducated" and having "low employability" (Arcadis Logos 2014a. v. IV: 178). It diagnoses the prevalence in the region of small-scale farming and cattle raising activities with scarce technology and very low productivity, "producing results of low efficiency" (Arcadis Logos 2014a. v. III" 264). Using quantitative indicators in their study, such as the Human Development Index (IDHM) and per capita income to affirm "that the IDHM of 0,616 for Santa Quitéria and of 0,56 for Itatira (IBGE 2010) characterizes a situation of misery of the population of the region, which should be overcome by imitating the model of regions with better scores for economic indicators, that is, by incorporating the capitalist urban-industrial system", as Melo analyzes (2015: 132), based on Zhouri and Laschefski (2010). In addition, in the seminar Renewal of the project of exploration of the Itataia mine and its economic importance for Ceará (2013), a federal congressman justified the project as a development opportunity, since "it is a region fated to live in extreme misery, without alternatives" (Melo 2015: 132).

In response to this situation characterized as misery, the powerful conception of development as "salvation" (Montezuma 2015) or "redemption"3 (Monteiro Junior 2017) underlies these narratives and promotes important political support for the Project:

Summarizing, municipal authorities were favorable to the Santa Quiteria Project, with expectations of generation of employment, income, development and revenue for the municipality, as well as road construction which, in turn, would make possible investment in the region, with caveats regarding environmental degradation and burdening public facilities and, principally, possible health problems and contamination caused by the exploration of uranium (Arcadis Logos 2024a. v III: 618).

3 It is noteworthy that the Brazilian writer Jorge Amado, in his work entitled Tieta do Agreste, speaks of the announcement of implementation of the Brastânio - a titanium dioxide factory in the coastal paradise community of Santana do Agreste and, in 1976, describes with acuity the construction of the narrative of the entrepreneurs regarding "progress" and of "development", creating the motto "The Brastânio is the redemption of the Agreste!" 
In addition, the state government of Ceará has publicly defended the enterprise, emphasizing perspectives for a new pole of regional development. The Ceará state government is also committed to invest public resources for the construction of infrastructure required for mining operations, especially the water pipeline and widening of roads - long-time demands by citizens of the State, recognized only now, when required by the mining project.

In the narrative of development-as-salvation-from-misery, employment earns higher value, when compared to autonomous labor conducted by residents on their lands. The latter is signified as negativity reflected in the "high index of informality of labor relations":

More than one thousand workers will be hired to construct the Santa Quitéria project and approximately three thousand direct and indirect jobs will be created when it is in operation. Thus, Santa Quitéria will contribute to the improvement in living conditions of residents and to the development of the region as a whole. With more jobs will come job training courses, more water in people's houses and more revenue for the municipal government. Consortium Santa Quitéria, giving value to the natural wealth of our region. (Excerpt of a video that introduces the Consortium, shown at the start of public hearings, on November 19, 20 and 21, 2014).

Thus, as in other enterprises, job creation has been posited as the legitimating argument for the project by agents of the State and the consortium. For some residents, employment would be the benefit, "in exchange for" the mining: "because the harm we'll just have to accept. So we'll gain a little of something which is good, if there is...", commented one of them after the public hearing (Montezuma 2015: 121). The argument of job creation is employed repeatedly and incisively, especially for the young people, including in public schools, as a promise of entrance into modernity:

We were always told by teachers that the Santa Quitéria Project would become a reality and that it would open up many opportunities, especially for young people concluding the third grade, and that there would be many employment opportunities, that it would be good for the community, that the community would develop (Young student from Itatira interviewed in Brasileiro, 2017).

Nevertheless, the situation verified in the settlements and communities of the region does not correspond to the stated "extreme poverty", as also noted in other studies conducted in Brazil (Laschefski 2011; Monteiro Junior 2017). After gaining land, through struggles mobilized by the MST and by the Rural Farmworkers Unions of the region, residents drew on their knowledge of living in the semiarid and living in community to organize movements related to public policies and access to resources for housing and necessary infrastructure. They coordinated their activities with NGOs which provide assistance in the technology of water catchment, both for human consumption as well as for agro-ecological production and are constructing their own territoriality in the countryside, "based on personal and primary relations, structured around the family and ties of solidarity, informed by kinship, with the community as the basic social unit" (Marquez 2004 apud Laschefski 2011: 30). Although not all have access to land, and the majority feel the need for greater help from public health, education and agricultural production policies; many of the native narratives reaffirm the peasant way of life:

Studying and thinking about mining, thinking about migrating to the South, that is, Rio de Janeiro and Sao Paulo, that's not the solution. I think it would be better for young people, mayors and city councilmen to do consciousness raising for young people to live and produce in the countryside [..] This young person who finishes his studies in the countryside has the mentality, the knowledge, that you can also be happy living in rural areas and producing quality foods, and passing on the fruit of their production so that children in the school in our town can eat healthier food (Resident of the community of Riacho das Pedras, Santa Quitéria, interviewed in Monteiro Junior 2017: 144). 
Thus, the alternative of "development" and employment which the project would bring is in confrontation with the project of peasant territory, constructed over a period of decades, thereby dividing residents of the communities and the settlements. In conversations with the latter, new questions are raised - "but what is going to be the price of these jobs?", "why doesn't anyone come and speak about the risks?" (Brasileiro 2017) - requiring the provision of additional information, the access to which is often not facilitated, as we will discuss next.

b) Inequalities in access to information about the project and its consequences and the road to a lay epistemology

Since the beginning of 2000, there has been an increased presence in the area of the Itataia mine of biologists, geologists, sociologists, physicists and various other professionals, conducting field studies required for the elaboration of the EIA. They interact with communities of the region, seek information and even people who can act as guides, transport equipment, provide water or meals. It was through them that residents learned that the mining project was moving forward. Probing possibilities of transformation in their territory, they shared these fragments of information in daily conversations or in community association meetings, tried to "connect the dots", raised hypotheses and learned something additional to test their hypotheses, while a feeling of insecurity about the future of their place took hold (Figure 3).

Figure 3 - Residents of the communities visit the site planned for the enterprise and talk about its consequences.

Source: Acervo Nucleo Tramas/UFC

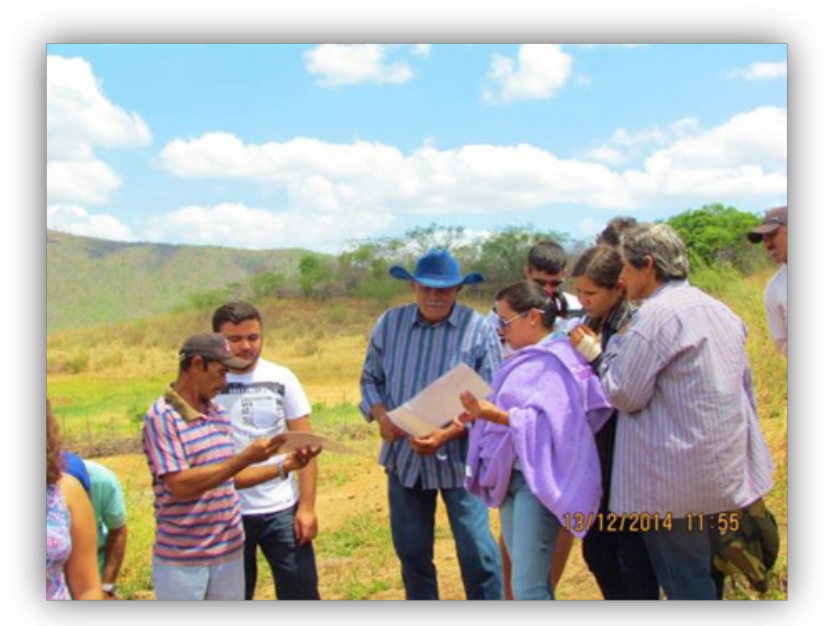

At the same time, a variety of processes were occurring in meetings between entrepreneurs and public agents, for which the territory is essentially a profitable mineral deposit, and much information was produced and circulated, without community participation: mining authorization, locational alternative, environmental and nuclear licensing, negotiations over resources to be invested by the governments, the elaboration of pacts of assistance, definition of public relations strategies, etc.

In April of 2014, the EIA was finally made available by the federal agency responsible for the licensing the Brazilian Institute for the Environment and Renewable Natural Resources - IBAMA. Also made available at that time was the Report of Environmental Impacts - RIMA, required by legislation with the objective of providing information about the project in language accessible to the society. Thus, in addition to having been excluded from planning and decision-making phases of the project for more than a decade, 
those people who would likely be affected had only seven months to prepare for debate about the project in the public hearing. Seven months is actually a very short period of time for preparation, considering the complexity and large size of the project, as well as the specificities of its appropriation by local residents.

Furthermore, civil society did not have access to certain types of important information concerning the mining project beyond localized impacts, such as risks generated at a broader geographic level. The EIA announced "risks identified by the Santa Quitéria Project excluded risks referring to nuclear substances, in this case, uranium, which will be evaluated by experts in this type of substance" (Arcadis Logos 2014a. v. IV: 534). In a simple and daring operation ${ }^{4}$, the consortium completely removed risk evaluation related to radioactivity from public debate and submitted it to an unidentified group of experts. We emphasize that this is precisely one of the major concerns of residents with regard to consequences of the project, identified and recorded even in the EIA: "the great fear of those communities contacted refers to potential health problems caused by radiation, soil and water contamination, etc.” (Arcadis Logos 2014a. v. III: 698).

According to Montezuma, in the public hearings (November, 2014) "one of the participants submitted a written question about risks of radiation during mining operations:"

Despite the fact that presentations dealt with the environmental impact, I consider the information merely superficial. Those risks considered natural are already known. However, I would like to hear about risk during mining operations. What will be the radiation levels reached? (Montezuma 2015: 217).

The author continues, affirming that "IBAMA considers that the question has already been addressed and that we should move forward". A modus operandi of cognitive injustice is thus unveiled, actively produced by the entrepreneurs by making it difficult for those threatened by the project to learn the full extent of project-related risks. This strategy diminishes the value of the public hearings as public spaces of participation and debate, making them merely a circumscribed, devalued space of "environmental adequacy" in which palliative measures of mitigation and compensation of project-related damages are presented (Zhouri, Laschefski and Pereira 2005).

In turn, communities recall the period of drilling of the mineral deposit (1970s) and share memories of accidents which occurred, including the fire; they exchange information about the presence of technical personnel and their activities in the territory, and take their concerns to the movements and groups with which they exchange ideas. That is the context in which the AACE - Antinuclear Articulation of Ceará was constituted. The AACE dealt with the demand for greater knowledge about the project and organized educational seminars for local residents. Through their ties with the Brazilian Network for Environmental Justice and the Brazilian Antinuclear Articulation, AACE promoted interchanges with subjects of the municipality of Caetité, in the state of Bahia, site of the only uranium mine in Brazil currently in operation.

The visit of people from Ceará to that region of Bahia made it possible for residents of Santa Quitéria and Itatira to more fully comprehend the nature of a project of this size, and its consequences, after talking with local residents about their difficulties in marketing their agricultural products in the open markets in the municipality due to suspicion of radioactive contamination; visualize the cracks in the walls of their houses due to explosions during mining operation; hear from mineworkers stories of precarious and insecure working conditions in the company and the perception of increased cases of cancer; identify similarities in company and institutional strategies adopted in the two states and discuss strategies of resistance.

4 According to Brazilian legislation concerning radioactive minerals, environment licensing of the enterprise should also include nuclear and mineral licensing, as the EIA itself recognizes (Arcadis Logos, 2014a, Vol. I: 44). Nevertheless, the consulting firm, probably in accord with the proponent of the project, omitted nuclear licensing from the environmental licensing proposal and submitted the studies in that way to the national licensing agency. 
Well before the meetings I was completely in favor of the mine. I was convinced that it would be better for our community. Also, for our country [...] More and more I began to think that the opposite was true. About the bad things that would happen to our health. Examples from people in Caetité, of people who lived through this. People telling how nobody wanted to buy any more food produced in the region. And how I thought that it would change their lives and how what happened was totally the opposite (interview with resident of Riacho das Pedras in Monteiro Junior 2017: 126).

Residents and social movements perceived the value and importance of this dialogic process of knowledge construction, which facilitated the development of independent, informed evaluations regarding the consequences of the project for the lives of local residents. In order to follow up on this perception and expand the process to a greater number of people, they organized an event entitled The Present which we have in Caetité-Bahia and the Future we want for Santa Quitéria-Ceará. Organizers brought to Ceará a farmer, resident of the periphery of the mine in Bahia, an employee of the company, a local priest and a representative of the NGO Movement Association Paulo Jackson. The event took place in the two communities which would be affected (Figure 4), as well as in the capital of Ceará, with the purpose of involving social groups in the resistance to the mining project.

Figure 4 - Scene from the I Antinuclear Day of Ceará, showing participation of people from Caetité/Bahia Source: Acervo Núcleo Tramas/UFC

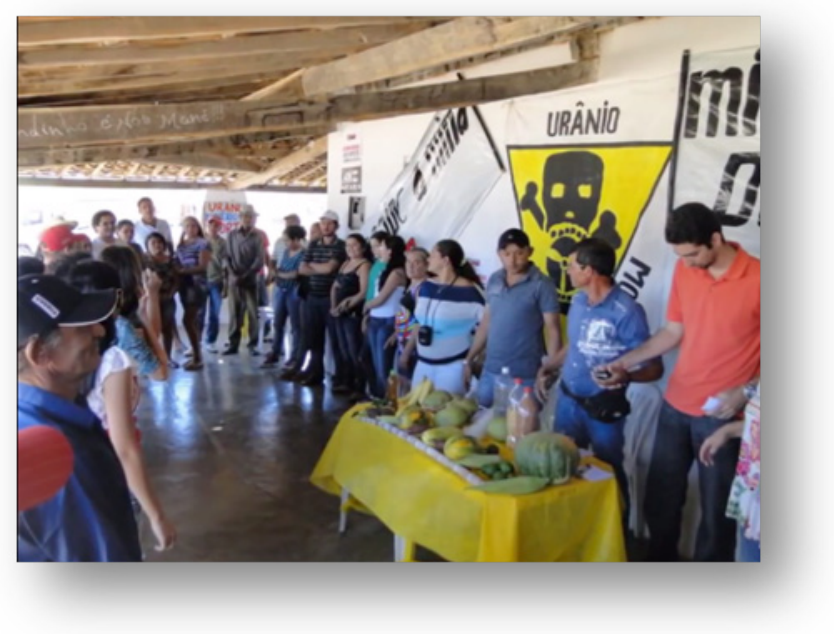

Following this event, others included the II and III Antinuclear Days of Ceará, en 2014 and 2016, as well as activities in the communities in preparation for public hearings sponsored by IBAMA, as part of the effort to increase access to information and strengthen the argumentative capacity of local residents: "my opinion today is 'no', and now I know how to say why"s (interview with young student in Brasileiro 2017).

These types of activity are informed by the notion of environmental justice, constructed by social movements in struggles which make claims for policies which assure broad access to information about the project and its consequences. These movements also demand "democratic and participative processes in the definition of policies, plans, programs and projects which affect them"; and support the "formation and active participation of collective rights subjects, social movements and popular organizations" (RBJA 2001).

5 And she continues: It's because it's no use wanting a small city to grow in size, population, if it is going to bring bad things. Because it's going to bring not only diseases, but also more robberies, more deaths, more prostitution. Not that we don't have that now, but not as much. But so many young people are going to come here, thinking it's one thing and discovering that it's something totally different. And so before, some of my classmates were in favor, and they still are today, but when you ask each one of them why they are in favor, they give you the same answer. It's always the same answer. 'It's going to bring a lot of money here, we're going to have more development and more jobs'. But what are these jobs going to cost?!"” 


\section{c) Scientific controversies and dialogue for shared knowledge construction}

In addition to the omission of the problem of radioactive contamination in the EIA, the RIMA disregards issues central to public concerns: for example, the word cancer or its synonyms do not appear even once in the pages of the document, although it is the risk most closely associated with the productive chain of uranium in the scientific literature, and recognized as such by national legislation (Radonseal 2012; Rericha et al 2006; Taeger et al 2006). When questions regarding these probable consequences of the project were raised by residents and social movements, the consortium rearticulated less generic communication strategies and responded in that way to concerns brought to the public arena. With respect to cancer risk associated with the productive process, the newspaper distributed by the company cleverly called Daqui (From Here, in the sense of fostering identity with the place) offered, under the title Overcome your doubts about the project, the following "information":

Is uranium dangerous to human health?

A variety of international research projects, carried out in sites where there are large mineral reserves, demonstrate that natural uranium does not produce a large number of cases of cancer or other disease directly from the radiation (newspaper Daqui, Santa Quitéria, s.d.).

Such a statement can be analyzed as perverse information (Acselrad, Mello e Bezerra 2009), to the extent that it associates the adjective "natural" with uranium, relating it to the idea of beneficence, and which omits the fact that 118 tons of minerals containing uranium will be extracted from the subsoil, crushed and ground above-ground, profoundly and radically altering the "natural" conditions in which it is found - that is, "awakening the dragon", according to native expression. Furthermore, it appropriates and interprets available scientific knowledge in accord with its own interests: in fact, the element uranium (U238) is known to cause kidney alterations, but it is widely known that it is an unstable metal which associates fourteen chemical elements known as children, in a chain of decay which emits radioactive particles alpha and beta in each transformation. Among these is the gas Radonio (Rn222), recognized as the second highest cause of lung cancer in the world (Randoseal 2012).

Funtowicz and Ravertz recall that, on the one hand, the Illuminism contributed to the spread of the belief that public decisions should be supported by rationality and scientific expertise - "supreme authorities, holders and providers of practical wisdom". These author alert, however, that it is incumbent on us today to recognize that this scientific rationality is not stripped of values and is not neutral ethically; that the definition itself of the problem is coerced by political considerations and interests and the composition of the scientific field is biased by social groups which have access to scientific training (Funtowicz e Ravert 1997: 221).

In turn, agents of the State, committed to the consortium in acquisition of licenses for mining, actively participate in the process of the concealment of risks, denying public concerns and disqualifying those narratives which are counter to the enterprise. In the public seminar Renewal of the Itataia Mining Project and its Economic Importance for Ceará, organized in 2013 by a Federal congressman together with entrepreneurs, the mayor of Santa Quiteria affirmed the following:

Our democratizing the information is to demystify notions of the past and, once and for all, end fallacies that the mine will contaminate, that the mine is prejudicial, that the mine is going to bring evil spells...Through this democratization of information we perceive that these fallacies and these incorrect notions are going to fall by the wayside. So it is important that events like this happen more frequently. Moments like this when we can once and for all put an end to the issue of not exploiting the mine, of not developing (Ribeiro 2016: 46). 
Thus the highest municipal authority, by characterizing as mystical, fallacious and incorrect those arguments which question the consequences of the project which would bring development to the municipality, clearly expressed his intention to close debate on the risks of the mining enterprise. The idea of democratization of information was appropriated not in the sense of expanding its access to public debate, but rather to refer to the dissemination of the perspective of the enterprise, which supposedly would have arguments to successfully counter opposing arguments. According to Ribeiro (2016:46), the following types of statements in that Seminar were frequent: "there's a lot of prejudice about this mining project"; "there's a lot of incorrect information"; people are imagining many things"; "radiation is in the whole environment, but it can be monitored, without any problem"; "people shouldn't worry about inspection, because the responsible government agencies do this very well".

Another important public concern is with respect to water, since it is a semiarid region where there is a shortage of water. The state government agency responsible for water management was urged to submit a technical report to IBAMA regarding the viability of the mining company's requirement of 8.030 .000 cubic meters of water for each year of operation, or 1.100 cubic meters per hour (Arcadis Logos 2014a: 468). The agency presented a text which, in the analysis of Araújo e Ribeiro (2016), violates basic concepts and methods of hydrology to conclude that "the region's access to water has positive perspectives".

State agents prematurely committed themselves in favor of the project, abdicating their role in critical analysis of the enterprise and in complying with the law, to the prejudice of the protection of citizens and generating new controversies (Acselrad 2013). In turn, the consortium even lied during public hearings, with respect to the concern expressed by one resident regarding the risk of rupture of the tailings dam which is situated on a course of water - and of contamination of crops downstream. Ordered to respond, the engineer responsible for the tailings dam informed that this water would contain, at the maximum, sand and clay, when the EIA itself recognized that it would be contaminated from radium and thorium which was denounced soon after by a researcher, citing volume and page of the document, and leading the engineer to apologize for his "mistake".

The above example illustrates that the evaluation of occupational and environmental risks related to uranium and phosphate mining is challenging even to the scientific field. Clearly, then, it is even more difficult for the population to evaluate the consequences of the project for their lives, in the very limited time and precarious conditions fixed for public information and participation. The AACE sought to deal with this inequality by demanding that the Núcleo Tramas/UFC elaborate an expert opinion about the project. This request was accepted, with the formation of an Academic-Popular Panel, composed of researchers from the areas of physics, medicine, geology, economics, anthropology and law. The panel analyzed the 4800 pages of the EIA and sought to integrate their critical analyses, producing a report which identified numerous methodological inconsistencies, insufficiencies of information and studies, and highlighted aspects related to the identification, magnitude and consequences of risks to health and environment (Rigotto et al, 2014).

With the help of the AACE, the panel then participated in community meetings in which the researchers attempted to simplify the scientific knowledge to allow for active dialogue with local residents (Figure 5). Based on their situated knowledge about the ecosystem and the organization of social life, local residents discussed and supplemented analyses presented by the university personnel, raised questions which had not been anticipated by the researchers - such as contamination of their drinking water

6 The document entitled "Studies of guarantee of meeting future demands in the Acaraú Water Basin, considering the influence of implanting the Santa Quitéria Project", elaborated by the Secretary of Water Resources of Ceará - SRH - and by the Water Resources Management Company of Ceará - COGERH - considers the total supply of water of the area of study as being equal to the sum of the storage capacities of the dams, not taking into account losses by evaporation, bleeding and infiltration and, principally, the hydric deficit characteristic of the semiarid and the five-year period of drought which has afflicted the state, basing its conclusions on the false premise that the reservoirs show 100\% capacity of storage (Araújo e Ribeiro 2016). 
reservoirs, supplied by rainwater drained from rooftops, which could be contaminated by the deposit of toxic and radioactive dust - and both groups shared their doubts.

Figure 5 - Research geologist of the UFC in dialogue about the EIA with community of Riacho das Pedras, Santa Quitéria, 2014. Source - Acervo Núcleo Tramas/UFC

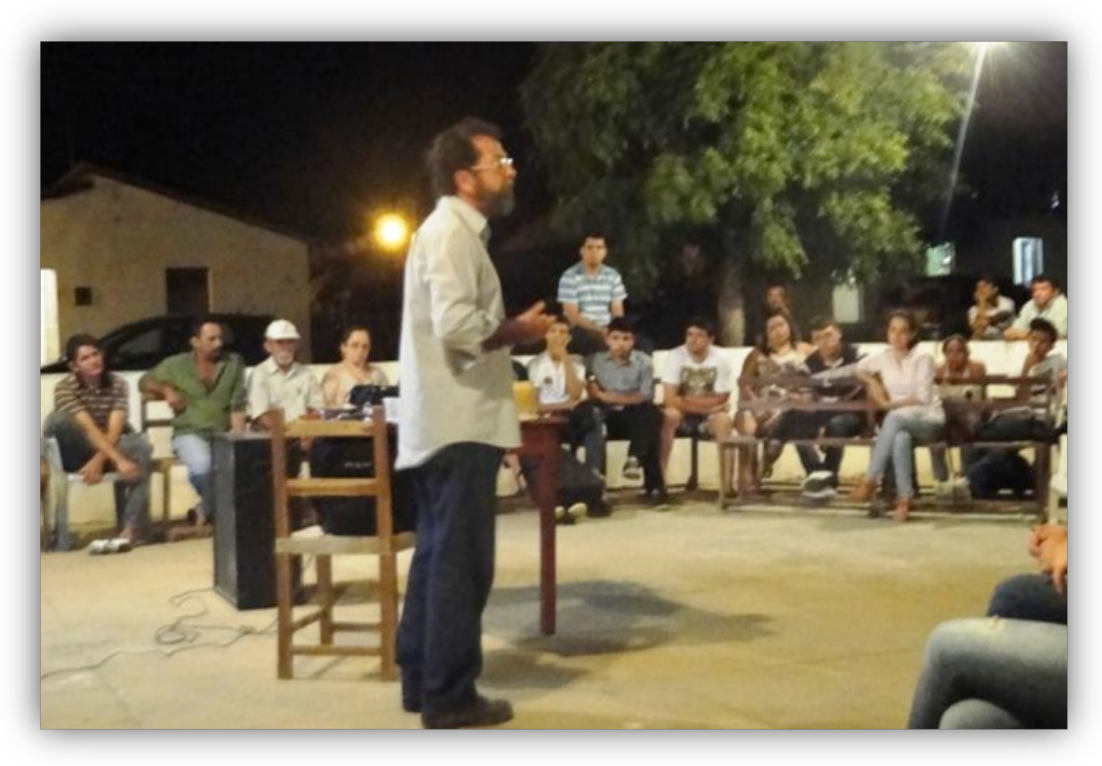

Thus a dialogic process of shared knowledge construction was promoted (Santos e Meneses 2010; Porto 2011; Porto, Rocha e Finamore 2014) which strengthened the argumentative capacity of the local subjects. This was reflected in their oral presentations in the public hearings sponsored by IBAMA, although they were allowed only three minutes to express themselves. It also contributed to the expert opinion elaborated by the Panel, which provided the basis of a representation submitted by the AACE to the Public Ministry and the Public Defender, which has had some influence on the actions of these agencies in the environmental licensing process and in the elaboration of the technical opinion of IBAMA following the public hearings. In this manner, renewed paths are tested for the production of quality knowledge, which is useful in the defense of life, as we will discuss in the final section of this article.

d) Power inequalities in the production and dissemination of knowledge about the enterprise and resistance to it

The entrepreneurial consortium has been able to draw on an ample group of technical professionals to produce narratives relating to the uranium and phosphate mining and processing project. This technical group includes engineers, chemists, physicists whose verbal presentations in public hearings were often in relation to the denial or minimization of risks. Prior to each presentation, they pretentiously cited their academic achievements and titles, attempting to show that these credentials ordained them with the power of "public authority of science" (Wynne 2014).

The entrepreneurs have the support of the team of the consulting agency which elaborated the EIA (paid for by the consortium, we emphasize), which included several well-known researchers from public universities, particularly in the field of Public Health - since "discourse always owes a very important part of its value to the value of he who controls it, much more than how much the social agent controls the grammar that he speaks" (BOURDIEU 1977: 9). These consulting firms have a determinant role in the 
construction of discourse for public settings and rationalized strategies of relationships with other social subjects, geared toward the production of social acceptance. To this end, they consolidate a narrative which affirms the socio-environmental responsibility of companies and their technical capacity of risk management, emphasizing "credibility", "seriousness", and "history of good practices" which form the new entrepreneurial ethic (Bronz 2011: 85).

The consortium further increases the asymmetry of power between the social groups in dispute by investing part of its resources contracting a firm specialized in public relations, which includes professionals specialized in a variety of areas of the human and social sciences. This firm develops actions directed toward a wide range of social actors, from the establishment media, where it frequently submits "news" which boasts of the advantages of the enterprise or which pressures public authorities to provide greater support to the project or to accelerate the pace of the licensing process, in headlines such as "Itataia will revolutionize the economy of the hinterlands", "License for the Itatiaia plant will probably be approved in the coming days"8 or "Construction for Itataia plant expected in 2016"9 (Montezuma 2015).

Considering the importance of public support by the State apparatus, as an actor which confers legitimacy to the enterprise for its supposed posture of neutrality, the consulting firm drew up a broad plan of action geared toward public sector actors. In addition to the announcement and the materiality of economic advantages for state and municipal governments, the consortium arranged transportation to take mayors, city councilmen, and municipal health and environmental secretaries to Caetité, Bahia, to hear testimonials from their peers about the benefits of the ongoing mining operations, in a strategy which followed the above referenced interchange between residents and workers of the two affected municipalities, organized by the AACE.

A specific intervention strategy was developed to relate to those communities faced with the prospect of having to deal with the harmful features of the project, and which constructed a strong process of resistance, supported by shared knowledge construction. That strategy consists of actions including becoming friendly with subjects most important locally in opinion formation - even presence at birthdays and tributes on Fathers' Day - as well as proposing projects which associate the offer to construct a deep well for drinking water to setting up experiments with chemical fertilizers in one of the communities.

At the level of local society, the company contracted to manage public relations created a toolbox which includes "a site with information about the project, and maintains a citizen information center in Santa Quitéria. In addition, it established a radio station in the region to disseminate information about the project, and produces pamphlets about radiation, water and contamination, material which is used in pedagogic work in the schools of the region" (Melo 2015: 143-4).

Thus, the project entrepreneurs construct powerful strategies to disseminate their narratives, using their economic, political and symbolic capital. These narratives reach a considerable segment of the population. In turn, AACE has prioritized dialogue with communities and with those researchers engaged in the Academic-Popular Panel, to produce discourses which contest "arguments presented by the consortium and by the State regarding environmental and social feasibility of the project, as well as contesting the managerial capacity and discourse of eco-efficiency of the companies" (Montezuma et al. 2016: 208).

7 http://www.oestadoce.com.br/noticia/itataia-revolucionara-economia-dos-sertoes

8 http://diariodonordeste.verdesmares.com.br/cadernos/negocios/licenca-para-usina-de-itataia-deve-sair-nos-proximos-dias-1.1338255. Accessed May, $14^{\text {th }}$ 2014 9 http://diariodonordeste.verdesmares.com.br/cadernos/negocios/usina-de-itataia-obras-previstas-para-2016-1.1065077>. Accessed May, 14 ${ }^{\text {th }}$ 2014 
Nevertheless, there is an enormous asymmetry in the power of dissemination of these counternarratives, as a result of the dynamics of an environmental field marked by hierarchical positions and very unequal power relations. The AACE recognizes the limits of their ability to reach communities expected to be affected. These limitations are due to the following factors: difficulties of the social movements and entities which make up the AACE with regard to the territorial mobility and time availability of militants for these activities; difficulty in obtaining speaking time on local radio stations or publishing in the written media; and in scheduling meetings with public authorities or obtaining answers to questions posed to public agencies.

In their effort to deal with this inequality, AACE developed strategies of producing communication materials, such as the documentary-video From Caetité (Bahia) to Santa Quitéria (Ceará): the sagas of uranium mining in Brazil, available on the Web ${ }^{10}$, which records the learning process constructed during the interchange between residents of Santa Quitéria and Caetité. In addition, through the NGO Caritas of the Sobral Catholic Church, AACE elaborated the pamphlet entitled: In Ceará: the struggle of life against Uranium, which highlights "the strong peasant culture ingrained in the life of the people" of the region and presents the mining project as a possible "second stage of a reverted latifundio of developmentalist idealism" (CDS: 2013: 3). AACE also developed infographics to improve communication regarding the most critical aspects of the mining project.

Figure 6 - THREAT to the waters of the semiarid region of Ceará: the expected hourly consumption of water of the uranium and phosphate mining project in Santa Quitéria is equivalent to 115 water distribution trucks ${ }^{11}$.

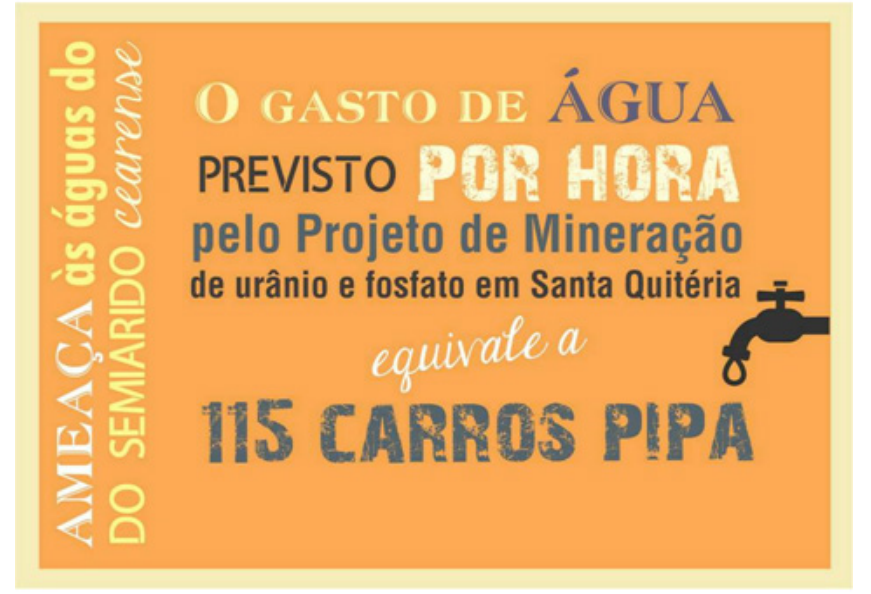

These materials were important examples of autonomous processes of knowledge construction about the project and materials used for training and debate with communities, institutions and social movements of the region, although the quantity and reach was much lower, in comparison to materials produced by the consortium.

10 www.youtube.com/watch?v=4SA_-ClFaZA. Accessed February, $12^{\text {th }} 2017$ 11 Carro pipa refers to trucks which supply water to local communities in periods of drought. 


\section{Final considerations}

The course of the knowledge production process discussed within the context of the environmental conflict in Santa Quiteria illustrates the argument that the radical denial of the existence of native peoples "beyond the equator" has persisted for centuries. Even after the independence of the colonies, this process has continued to adapt and territorialize in the global South to the extent that "modern western thought continues to operate along abyssal lines" (Santos and Meneses 2010: 39).

The production of symbolic legitimation and support of development projects involves discourses and practices which imprison in the past the wisdom and ways of life which resist the paradigm of globalized capital (Castro-Gomez 2007). The people who construct these territories are represented as non-subjects. Their existence is often denied, even in maps which locate the mining projects (the supposed "demographic emptiness"). Even when their existence is recognized, they are treated as incapable of participating in decision making processes about the future of their territories because they lack knowledge to contribute to these debates.

They are excluded from macro-processes of economic and political decision making. "Participation" required in environmental assessment procedures is restricted to the paradigm of environmental adequacy, in which the project is presented as inevitable and which "exemplifies the dynamics of an environmental field marked by hierarchical positions and very unequal power relations" (Zhouri 2012: 46-47). Public concerns are treated as doubts due to ignorance, which, when not ignored or disregarded, are clarified by a supposedly unique and unbiased expert knowledge. In this manner, the epistemicide and cognitive injustice which compromise their possibilities of self-defense as a social group, is compounded by the expansion and vulnerabilization of people affected, and of others likely to be affected, as a result of the materiality of the advance of expropriation and spoliation.

Nevertheless, it must be recognized, especially in a context of a global eco-systemic crisis and crisis of civilization, that these local subjects maintain precious knowledge and values about life and community organization, and about relations with nature. This knowledge and these values can illuminate important alternative paths of development and modernity for humanity. In a world headed for a collapse of water supply, they know how to live day-by-day with little water; in a planet in which there is an increasing number of regions with desertification processes, these people produce food security in the semiarid; they maintain seeds free of transgenics - which will be a source of a renewal in production of healthy foods, when hegemonic science finally recognizes the risks of GMOs. The importance of these knowledges, as well as that of many others, is worthy of being recognized, valued and preserved as collective common goods of humanity. More than that, "this lay wisdom - known as 'situated' by cultural studies of science - is not simply wisdom which complements and democratizes the decision in the cognitive plain; it is also political wisdom which situates remaining subjects, including dominant epistemic subjects", as argued by Acselrad (2014: 102). In this scenario, an important role is played by practices established in the field of science, hegemonized by the interests of economic agents, in knowledge production which facilitates the subordination of nature to the expansion of frontiers of accumulation, as well at the creation of technological risks imposed by large enterprises in the territories. It is an "economy of knowledge" that promises nothing less than:

...the end of the frontier between public and private research, with direct appropriation of that which, until now, had the benefit of a quite relative autonomy. Knowledge production is today considered an issue too important to leave this minimum of autonomy to researchers, henceforth submitted to the imperative of forming partnerships with industry, of defining the registration of patents as desirable success par excellence 
and the creation of spin off ${ }^{12}$ as the dream of glory. All this with public money, which will be devoured in the various spin-offs which fail, while those successful will be reacquired with little risk, with their patents, by this or that consortium. Summarizing, there has been a change in the distribution between what the State allows capitalism to do and what capitalism makes the State do (Stengers 2015: 74-75).

It is in this scenario that one can understand the "exclusion of the 'lay public' with their repertory of values, meanings and life experiences" and "autonomous capacities and legitimate rights as common citizens" in public debates which involve science (Wynn 2014: 92); and also understand strategies of inhibiting academic debate, by means of "judicial inquiries, prohibitory interdictions, demands for the professional de-accreditation, pressures on university presidents in opposition to research projects" (O’Dwyer 2014; Wynne 2014). These strategies are applied to segments of the scientific field which assume autonomous and critical positions in political-cognitive conflicts.

It is noteworthy, however, that within the scientific field there are also ruptures and movements constituting new academic practices - for example, what is happening in the field of Anthropology. Research is being conceived in partnership with those affected by large development projects, involving these groups "meaningfully in the definition of objectives and the means of carrying out research", conscious of ethical and political responsibilities of the research. New forms of relationship are being constructed between subjects, open to dialogue with local knowledge, constructing "communication communities" (Pacheco de Oliveira 2013: 48, 65).

From our perspective, new horizons are opening for a fertile encounter between several of the epistemic subjects highlighted in the characterization proposed by Acselrad (2014): those who strive to construct a lay epistemology which helps them defend their way of life and those who propose the democratization of cognitive powers, on the basis of critical and autonomous thinking. Re-signifying science and the very tripod teaching-research-extension, various groups linked to universities in Latin America and which have as their focus environmental conflicts, have constructed insurgent academic praxis, established on solidarity and dialogue with political and social subjects affected by development. In this encounter, they create powerful paths for the production of knowledges of quality - which challenge epistemological and methodological precepts of science, at the same time as they stress the democratization of the relation university-society and contribute to the training of young critical, reflecting and ethical researchers. In the context of the crisis of modern science, such groups point to paths for what could come to be an emancipatory science.

Translated by Franklin Rothman

Revised by Andréa Zhouri

Received on: March 22, 2017; Accepted on: April 25, 2017

12 Spin off: "Creation of a company by the transfer of technology from a research group [Editor's note]" (Stengers, 2015, p.: 75). 


\section{References}

ACSELRAD, H. 2014. "Disputas cognitivas e o exercício da capacidade critica: o caso dos conflitos ambientais no Brasil”. Sociologias, 16(35): 84-105.

. "O conhecimento do ambiente e o ambiente do conhecimento - anotações sobre a conjuntura do debate sobre vulnerabilidade". Em Pauta, 11(32): 115-129

ACSELRAD, H; BEZERRA, G. N.; MELLO, C. C. A. 2009. O que éjustiça ambiental? Rio de Janeiro: Garamond.

ALVES, P. A. 2012. Vigilância popular da saúde: cartografia dos riscos e vulnerabilidades socioambientais no contexto de implantação da mineração de urânio e fosfato no Ceará. Dissertação de Mestrado, Programa de PósGraduação em Saúde Coletiva. Universidade Federal do Ceará - Fortaleza.

ARAÚJO, J. C.; RIBEIRO, L. A. D. 2016. Parecer Técnico - Análise do relatório intitulado "Estudos de garantia de atendimento à demanda futura na bacia do Acaraú, contemplando a influência da implantação do Projeto Santa Quitéria”. Fortaleza, Universidade Federal do Ceará. Mimeo.

ARCADIS LOGOS. 2014a. Estudo de Impacto Ambiental - Projeto Santa Quitéria. São Paulo, Consórcio Santa Quitéria \& Arcadis Logos Consultoria Ambiental. Mimeo.

ARCADIS LOGOS. 2014b. Relatório de Impacto ao Meio Ambiente - Projeto Santa Quitéria. São Paulo, Consórcio Santa Quitéria \& Arcadis Logos Consultoria Ambiental. Mimeo.

BOURDIEU, Pierre. 1977. “O campo científico”. Actes de La Recherche en Sciences Sociales, 2/3: 88-104. Tradução de Paula Montero.

BRASILEIRO, L. A. M. 2017. Educação para transformação: uma experiência com juventudes do campo em contexto de conflito ambiental. Monografia de Graduação em Ciências Biológicas, Universidade Federal do Ceará, Fortaleza.

BRONZ, D. 2011. Emprendimentos e empreendedores: formas de gestão, classificações e conglitos a partir do licenciamento ambiental, Brasil, século XXI. Tese de Doutorado em Antropologia Social, Universidade Federal do Rio de Janeiro - Rio de Janeiro.

CASTRO-GÓMEZ, S. 2007. “Decolonizar la universidad. La hybris del punto cero y el diálogo de saberes”. In: S. Castro-Gómez; R. Grosfoguel (orgs.), El giro decolonial: reflexiones para una diversidad epistémica más allá del capitalismo global. Bogotá: Siglo del Hombre Editores. pp.79-92.

CBPDA. COLETIVO Brasileiro de Pesquisadores da Desigualdade Ambiental. 2012. "Desigualdade ambiental e acumulação por espoliação: o que está em jogo na questão ambiental”. E-cadernos CES, 17: 190-220.

CDS. CÁRITAS Diocesana de Sobral. 2013. "No Ceará, a peleja da vida contra o urânio”. Disponível em « «http://caritas.org.br/wp-content/uploads/2014/o1/No-Cear\%C3\%A1-A-Peleja-da-Vida-Contra-oUr\% $\mathrm{C}_{3} \%$ A2nio-FINAL.pdf $\rangle$, acesso realizado em 18.08.2015.

COSTA, D. S. 2015. Saúde em contexto de conflito ambiental: um direito ameaçado pela implantação da mina de urânio e fosfato no Sertão Central do Ceará. Dissertação de Mestrado em Saúde Pública, Universidade Federal do Ceará. Fortaleza

FUNTOWICZ, S.; RAVERTZ, J. 1977. "Ciência pós normal e comunidades ampliadas de pares face aos desafios ambientais". História, Ciência e Saúde, 4(2): 219-230.

LASCHEFSKI, K. 2011. "Licenciamento e equidade ambiental: as racionalidades distintas de apropriação do ambiente por grupos subalternos". In: A. Zhouri (org.), As tensões do lugar: hidrelétricas, sujeitos e licenciamento ambiental. Belo Horizonte: Editora UFMG. pp. 21-59.

MARTINEZ-ALIER, J; HEALY, H; TEMPER, L; WALTER, M; RODRIGUEZ-LABAJOS, B; GERBER, JF; CONDE, M. 2011. "Between science and activism: learning and teaching ecological economics with environmental justice organisations". Local Environment, 16(1):17-36 
MARTINEZ-ALIER, J.; ANGUELOVSKI, I.; BOND, P.; DEL BENE, D.; DEMARIA, F.; GERBER, J.-F.; GREYL, L.; HAAS, W.; HEALY, H.; MARÍN-BURGOS, V.; OJO, G.; PORTO, M.; RIJNHOUT, L.; RODRÍGUEZ-LABAJOS, B.; SPANGENBERG, J.; TEMPER, L.; WARLENIUS, R.; YÁNEZ, I. 2014. “Between activism and science: grassroots concepts for sustainability coined by Environmental Justice Organizations”. Journal of Political Ecology, 21: 19-6o.

MELO, R. D. 2015. Riscos ambientais e processos de vulnerabilização: diálogos e controvérsias em torno do Projeto de Mineração de Urânio e Fosfato em Santa Quitéria, Ceará. Dissertação de Mestrado em Desenvolvimento e Meio Ambiente, Universidade Federal do Ceará - Fortaleza.

MONTEIRO JÚNIOR, F. H. 2017. O Dragão de Itataia: mineração e modos de contestação e de legitimação dos discursos do desenvolvimento. Tese de Doutorado em Sociologia, Universidade Federal do Ceará Fortaleza.

LASCHEFSKI, K. 2011. "Licenciamento e equidade ambiental: as racionalidades distintas de apropriação do ambiente por grupos subalternos”. In: A. Zhouri (org.), As tensões do lugar: hidrelétricas, sujeitos e licenciamento ambiental. Belo Horizonte: Editora UFMG. pp. 21-59.

MONTEZUMA, T. F. P. F. 2015. Licenciar e silenciar: análise do conflito ambiental nas audiências públicas do Projeto Santa Quitéria, CE. Dissertação de Mestrado em Direito, Universidade Federal do Ceará - Fortaleza. .; RIBEIRO, L. A.; MELO, R. D.; RIGOTTO, R. M. 2016. "Resistências à mineração de urânio e fosfato no Ceará (Brasil) - sujeitos, estratégias empresariais e ações de contraposição". In: A. Zhouri; P. Bolados; E. Castro (orgs.), Mineração na América Latina: neoextrativismo e lutas territoriais. São Paulo: Annablume. pp. 203-228.

NUNES, B. S. 2013. A escola nas tramas do conflito: o olhar docente sobre a mineração de urânio e fosfato em Santa Quitéria (CE). Monografia de Graduação em Ciências Biológicas, Universidade Federal do Ceará Fortaleza.

O’DWYER, E. C. 2014. “Apresentação”. Dossiê Conflitos Ambientais: saber acadêmico e outros modos de conhecimento nas controvérsias públicas sobre grandes projetos de desenvolvimento. Antropolítica: Revista Contemporânea de Antropologia, 36: 11-25.

PACHECO DE OLIVEIRA, João. 2013. "Etnografia enquanto compartilhamento e comunicação: desafios atuais às representações coloniais da antropologia”. In: Bela Feldan-Bianco (org.), Desafios da antropologia brasileira. Brasília: ABA. pp. 47-74.

PORTO, M. F. S. 2011. “Complexidade, processos de vulnerabilização e justiça ambiental: um ensaio de epistemologia política”. Revista Crítica de Ciências Sociais, 93: 31-58.

.; FINAMORE, R. 2012. "Riscos, saúde e justiça ambiental: o protagonismo das populações atingidas na produção de conhecimento". Ciência \& Saúde Coletiva, 17(6): 1493-1501.

RADONSEAL. 2012. "Lung cancer risks from radon: the annual death toll of radon in homes" Disponível em: <www.radonseal.com/radon-health-risks.htm> 2012. Acesso em: 09/og/12.

RBJA. REDE BRASILERIA DE JUSTIÇA AMBIENTAL. 2001. Manifesto de Lançamento. Rio de Janeiro. Mimeo. RERICHA, Vladimír. 2006. "Incidence of leukemia, lymphoma, and multiple myeloma in Czech uranium miners: a case-cohort study". Environmental Health Perspectives, 114(6): 818-822.

RIBEIRO, L. A. D. 2016. Risco e injustiça hídrica no semiárido: contribuição à avaliação de equidade ambiental do projeto de mineração de urânio e fosfato em Santa Quitéria, Ceará. Dissertação de Mestrado em Desenvolvimento e Meio Ambiente - Universidade Federal do Ceará. Fortaleza.

RIGOTTO, R. M.; ROCHA, M. M. 2014. "Da crítica à ciência moderna à construção de novas práxis acadêmicas - a pedagogia do território e a ecologia de saberes”. International Coloquium Epistemologies Of The South, Coimbra. Mimeo. 
RIGOTTO, R. M.; AGUIAR, A. C. P.; COSTA, D. S.; ALMEIDA, E. F. 2014. "Análise do estudo de impacto ambiental do Projeto Santa Quitéria em suas relações com a saúde pública, a saúde dos trabalhadores e das trabalhadoras e a saúde ambiental". Parecer Técnico. Universidade Federal do Ceará e Universidade Estadual Vale do Acaraú. Fortaleza/Sobral. Mimeo.

SANTOS, B. S.; MENESES, M. P. (org.). 2010. Epistemologias do Sul. São Paulo: Cortez.

STENGERS, Isabelle. 2015. No tempo das catástrofes. São Paulo: Cosac Naify.

SVAMPA, Maristela. 2016. "Extrativismo neodesenvolvimentista e movimentos sociais: um giro ecoterritorial rumo a novas alternativas?” In: G. Dilger; M. Lang;, J. Pereira Filho (orgs.), Descolonizar o imaginário - debates sobre pós-extrativismo e alternativas ao desenvolvimento. São Paulo: Fundação Rosa Luxemburgo. pp. 140-173

TAEGER, Dirk et al. 2006. "Role of exposure to radon and silicosis on the cell type of lung carcinoma in German uranium miners". Wiley Interscience: 881-889. Disponível em: 〈www.interscience.wiley.com〉. Acesso em: 12 jan. 2006.

TEIXEIRA, A. C. A. 2013. "Territorialização em saúde: estudo das relações produção, ambiente, saúde e cultura na atenção primária à saúde”. Programa de Apoio a Projetos Institucionais com Participação de Recém Doutores - CAPES/UFC. Fortaleza. Mimeo.

WYNNE, B. 2014. “'Elefantes nas salas' onde os públicos encontram a 'ciência'?: Uma resposta a Darrin Durant. Refletindo sobre a expertise: Wynne e a autonomia do público leigo". Revista Antropolítica, 36: 83-110.

ZHOURI, A. 2012. "Belo Monte: crise do sistema ambiental e da democracia". In: A. Zhouri (org.), Desenvolvimento, reconhecimento de direitos e conflitos territoriais. Brasília-DF: ABA. pp. 45-65. .; LASCHEFSKI, K; PEREIRA, D. B. 2005. A insustentável leveza da política ambiental. 1a. ed. Belo Horizonte: Autêntica. .; LASCHEFSKI, K. (orgs.). 2010. Desenvolvimento e conflitos ambientais. Belo Horizonte: Editora UFMG. .; OLIVEIRA, Raquel. 2013. "Conflitos entre desenvolvimento e meio ambiente no Brasil: desafios para a antropologia e os antropólogos”. In: Bela Feldman-Bianco (org.), Desafios da antropologia brasileira. Brasília: ABA. pp. 75-108.

\section{Raquel Maria Rigotto}

Professor, Department of Community Health, Graduate Program in Collective Health, Medical School, Federal University of Ceará, Fortaleza, CE, Brazil

E-mail: raquelrigotto@gmail.com 